\title{
THE IMPACT OF FINANCIAL DEVELOPMENT ON THE ENVIRONMENT: EVIDENCE FROM CHINA
}

\author{
Sun Dong \\ School of Economic and Business Management \\ North China Electric Power University \\ Beijing, China
}

\begin{abstract}
With well-developed financial, it has become a hot topic whether financial development affect the quality of the environment, but the relevant literature is limited. In this paper, empirical approach is taken studying the relationship between financial development and environment quality, mainly using ADF, cointegration and Granger causality test. The model is established between carbon dioxide emissions and financial development based on the environmental Kuznets curve. The results reveal that the financial development is the Granger cause of $\mathrm{CO} 2$ emissions and suggest that financial development in China has not taken place at the expense of environmental pollution. On the contrary, it is found that financial development will lead to a decrease in environmental pollution if financial development is at a high level. It is concluded that carbon emissions are mainly determined by income.
\end{abstract}

Keywords: economic growth; financial development; environmental qualit

\section{INTRODUCTION}

China has witnessed a tremendous rate of economic growth and a high level of financial development over the last thirty years. At the same time, China now has become the largest carbon emitter in the world with the share $24.2 \%$ of the total in 2009(BP, 2010). While there is a fairly large literature investigating the link between economic growth and financial development, the impact that financial development has on the $\mathrm{CO} 2$ emissions is a topic that has, however, received very little attention.

The financial development in a country may attract foreign direct investment (FDI) and higher degrees of research and development (R\&D). This, in turn can, increase the level of economic growth, and hence, affect the dynamics of environmental performance. For example, Ang (2008a) pointed out that financial deepening in Malaysia leads to higher FDI inflows. Similarly, it has been found that financial liberalization plays a positive role in innoative (R\&D) activity in the case of Korea (Ang, 2010) and India. Jensen (1996) notes that financial development may lead to increased industrial activities, which, in turn, may lead to industrial pollution. It is against this backdrop that the resent article investigates the relationship between financial development and environmental pollution in the rapidly growing economy of China from 1953 to 2006.Chinese central government promised to reduce $40-45 \%$ carbon emissions intensity (carbon emissions per unit of GDP) by 2020 compared with the 2005 level. What is the role of financial development during reducing $\mathrm{CO} 2$ emissions?

Financial development, which broadly defined, refers to a country's decision to allow and promote financial activities like increased foreign direct investment (FDI), increases in banking activity, and increases in stock market activity. Financial development is important because it can increase the economic efficiency of a country's financial system and this can affect economic activity and the environment. Firstly, financial development may attract foreign direct investment (FDI) so as to accelerate economic growth and increase carbon emissions. Secondly, prosperous and efficient financial intermediation seems conducive to consumers' loan activities, which makes it easier for consumers to buy big ticket items like automobiles, houses, refrigerators, air conditioners, washing machines, etc., and then emit more carbon dioxide stock market development helps listed enterprises to lower financing costs, increase financing channels, disperse operating risk and optimize asset/liability structure, so as to buy new installations and invest in new projects and then increase energy consumption and carbon emissions. Tamazian and Rao(2010), in a study of 24 transition economies, find that financial liberalization may be harmful for environmental quality if it is not accomplished in a strong institutional framework.

However, there are also some authors opposing to the arguments above. Tamazian et al. (2009) emphasize that financial development lessens $\mathrm{CO} 2$ emissions in the BRIC countries. Besides, Claessens and Feijen (2007) find that those enterprises with more advanced governance often are more willing to consider low-carbon development; therefore, financial development helps listed enterprises to promote technology innovation and adopt new technologies, so as to increase energy efficiency and advance low-carbon economic development; consequently, the carbon emissions intensity may be cut significantly.

The rest of the paper is organized as follows. Section 2 presents the empirical literature review related with 
environment, carbon emissions and financial development. Section 3 puts forward research data definitions and empirical model in this paper. Empirical results and discussion are given in Section 4, and Section 5 concludes the paper.

\section{LITERATURE REVIEW}

There is a fairly large literature studying the link between economic growth and financial development. Financial development is important because it can increase the economic efficiency and this can affect economic activity .From a theoretical perspective, differences between the quantity and quality of financial institutions are an important determining factor for economic growth. More specifically, there are two different channels through which financial development can lead to economic growth ( Fung, 2009 ). Factor productivity is one channel through which financial development may lead to economic growth because financial innovations and technologies lessen informational asymmetries and this leads to better monitoring and selection of investment projects (P.Sadorsky,2010; Baier et al., 2004). The second channel, factor accumulation, emphasizes the spread of organized financial systems over self-finance. Organized financial systems increase efficiency as previously unproductive resources are put to better uses ( Bencivenga and Smith, 1991; Xu, 2000; Bell and Rousseau,2001). Consistent with this view that financial development leads to greater economic growth is the likelihood that energy demand should be positively impacted by increases in financial development (P.Sadorsky, 2010). We may see that the research about China's financial development and economic growth include three levels, i.e., on thenational, regional and provincial ones(Y.-J.Zhang, 2011).

Several existing studies on the relationship between economic growth and environmental conditions have argued that the level of environmental degradation and economic growth follows the inverted U-shaped relationship. This Ushaped relationship is known as the Environmental Kuznets Curve (EKC) in the literature. Existing research indicates that China's economic growth is closely related with carbon emissions; especially in the recent decade, we can see the significant driving influence of economic growth on carbon emissions ( Zhang and Cheng, 2009) and the restraining influence of carbon emissions on economic growth .

Comparatively, little research analyzes the influence of financial development on carbon emissions and environment. Sadorsky (2010) explores the influence of financial development in 22 emerging countries (including China) on energy consumption using a panel data model, and argues that, as a whole, financial development in these countries significantly promote the increase of energy consumption. Tamazian et al. (2009) investigate the relationship among economic growth, financial development and environmental quality in the BRIC countries, and find that financial development proves a key factor to cut carbon emissions. Similarly, Tamazian and Bhaskara Rao (2010) point out that financial development in transition countries may exert evident influence on carbon emissions.

As a whole, the previous related literature provides us with helpful references; however, as for the nexus of financial development and environment, specially carbon emissions in China, there are many problems to be investigated further. In this paper, two variables are chosen as China's financial development indictors, one is the commercial bank loan other than deposit, another is money supply.

\section{EMPIRICAL MODEL}

\subsection{Data Definitions}

When financial development is concerned, one of the popular definitions focuses on its scale, such as the sum of bank loan, stock market capitalization and bond market capitalization divided by GDP, but China's stock market and bond market emerged in 1990 and 2005 respectively, with very short time series, and its influence on the whole financial system of China appears limited till now; therefore, this paper does not consider stock and bonk market capitalization temporarily.

Meanwhile, according to King and Levine (1993), this paper used broad money (M2) ratio to nominal GDP to reflect financial depth. The increase in ratio (M2/GDP) means the increase in financial depth. But, in developing countries, $\mathrm{M} 2$ contains a large portion of currency. As a result, the rise of M2 may indicate monetization instead of financial depth (Demetriades and Hussein, 1996). It is noted that M2 is static variable at the end of the year, so this paper used the average value of $\mathrm{M} 2$ at the begin and the end of the year.

Besides, in order to avoid the omitted variables, economic growth is also introduced as an explanatory variable when the Johansen cointegration and Granger causality are tested.

All the variables in this paper and their data definitions are shown in Table I. It should be noted that all the data are the annual items and are transformed into logarithmic values for further investigation. The annual data of carbon emissions, GDP per capita and financial development indicators of China can be seen from Fig. 1. Most variables experience a steady rise across respective sample period, except financial intermediation efficiency with a relatively stable level even in a mild declining trend in recent years.

The data used in the present study are per capita $\mathrm{CO} 2$ emission, per capita real GDP, the ratio of broad money supply to GDP (denoted by LNM2), and the ratio of bank loan to GDP(denoted by LNLOAN) over the period from 1978 to 2007. 
TABLE I. VARIABLES AND DATA DEFINITIONS

\begin{tabular}{|c|c|c|}
\hline Variable & Definition & $\begin{array}{c}\text { Definition Sample } \\
\text { period }\end{array}$ \\
\hline $\mathrm{LNCO}_{2}$ & It denotes China's carbon emissions & $1978-2007$ \\
\hline LNAGDP & $\begin{array}{c}\text { It denotes China's economic } \\
\text { growth, represented by real GDP } \\
\text { per capita measured at constant } \\
\text { 1978 RMB }\end{array}$ & $1978-2007$ \\
\hline LNM2 & $\begin{array}{c}\text { It denotes China's financial depth, } \\
\text { represented by the ratio of broad } \\
\text { money supply to nominal GDP }\end{array}$ & $1978-2007$ \\
\hline LNLOAN & $\begin{array}{c}\text { It denotes China's financial } \\
\text { intermediation scale, represented by } \\
\text { the ratio of loans in financial } \\
\text { intermediation to GDP }\end{array}$ & $1978-2007$ \\
\hline
\end{tabular}

\subsection{Empirical Model}

The objective of this article is to analyze the effects of economic growth and financial development on carbon emissions in the case of China. Following Tamazian et al. (2009) and Talukdar and Meisner (2001), I use economic growth, financial development indicators and environmental

pollution in a single multivariate framework. Accordingly, a log linear empirical model is specified as follows:

$$
L N C O_{2}=\beta_{0}+\beta_{1} L N A G D P+\beta_{2} L N M 2+\beta_{3} L N L O A N+\varepsilon_{t}
$$

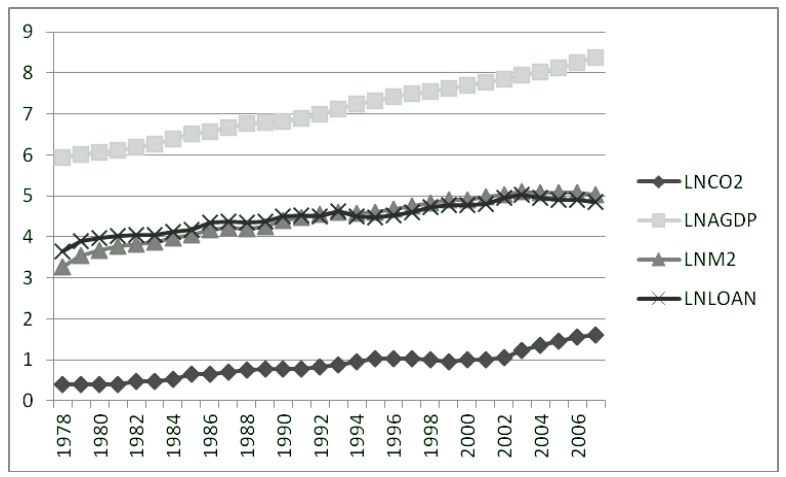

Figure 1. Annual log values of all variables in this paper

\section{EMPIRICAL RESULTS AND DISCUSSION}

\subsection{ADF Test}

This paper aims to investigate the long-term equilibrium relationship between financial development and environment based on the cointegration theory proposed by Johansen (1988) and Johansen and Juselius(1990), due to its advantages over traditional cointegration theory proposed by Engle and Granger(1987). Therefore, first of all, I conduct the augmented Dickey-Fuller (1981) (ADF) unit root tests for all variables in this paper in their respective sample periods and detailed results are shown in Table II. All variables in this paper are I(1) series at $10 \%$ level in their respective sample periods.

TABLE II. ADF TESTS FOR VARIABLES

\begin{tabular}{|c|c|c|}
\hline Variables & Level & First difference \\
\hline LNAGDP & $3.167465(-1.609070)$ & $-3.038717(2.632604)$ \\
\hline $\mathrm{LNCO}_{2}$ & $2.024542(-1.609798)$ & $-2.943966(-2.625121)$ \\
\hline $\mathrm{LNM}_{2}$ & $2.125899(-1.609798)$ & $-4.758892(-2.625121)$ \\
\hline LNLOAN & $2.641839(-1.610011)$ & $-4.907061(-2.625121)$ \\
\hline
\end{tabular}

\subsection{Cointegration Test}

Then according to Johansen (1988), I take China's carbon emissions as the dependent variable and each financial development indicator and GDP together as the independent variables using the Johansen cointegration test. The results are shown in Table III.

TABLE III. RESULTS OF JOHANSEN COINTEGRATIONTESTS

\begin{tabular}{|c|c|c|c|c|}
\hline $\begin{array}{c}\text { Hypothesized } \\
\text { no. of CE(s) }\end{array}$ & Eigenvalue & $\begin{array}{c}\text { Trace } \\
\text { statistic }\end{array}$ & $\begin{array}{c}\mathbf{1 \%} \\
\text { Critical } \\
\text { value }\end{array}$ & Prob. \\
\hline None* $^{*}$ & 0.574760 & 48.11313 & 44.49359 & 0.0473 \\
\hline At most 1 & 0.396228 & 24.17030 & 27.06695 & 0.1933 \\
\hline At most 2 & 0.229600 & 10.04265 & 13.42878 & 0.2774 \\
\hline At most 3 & 0.093188 & 2.738961 & 2.705545 & 0.0979 \\
\hline
\end{tabular}

Denotes rejection of the hypothesis at the $1 \%$ level.

Therefore, it may say that, for the most part, China's financial development has significant long-term equilibrium with carbon emissions as followed:

$L N \mathrm{CO}_{2}=-2.405+0.677 L N A G D P-0.058 L N L O A N-0.285 L N M_{2}$

According to Eq. (2), $1 \%$ growth of the real GDP will lead to the $0.68 \%$ increase of $\mathrm{CO} 2$ emission; the bank loan and the broad money supply rise $1 \%$ with the decrease of $\mathrm{CO} 2$ emission at $0.06 \%$ and $0.29 \%$ respectively.

\subsection{Granger Causality Test}

In order to assure the relationship among China's financial development variables and carbon emissions, it is necessary to conduct the Granger causality tests. .F-statistic and probability values are constructed under the null hypothesis of no causality. Results are shown in Table IV.

TABLE IV. CAUSALity TEST RESUlts

\begin{tabular}{|c|c|c|c|}
\hline Null hypothesis & $\begin{array}{c}\text { F- } \\
\text { statistic }\end{array}$ & Prob. & Result \\
\hline $\begin{array}{c}\text { LNAGDP does not Granger cause } \\
\text { the change of CO2 }\end{array}$ & 2.51014 & 0.10326 & Rejected \\
\hline $\begin{array}{c}\text { LNM2does not Granger cause the } \\
\text { change of CO2 }\end{array}$ & 3.50077 & 0.04707 & Rejected \\
\hline $\begin{array}{c}\text { LNLOAN does not Granger cause } \\
\text { the change of CO2 }\end{array}$ & 2.05566 & 0.15088 & Rejected \\
\hline
\end{tabular}


It is evident that there is a causal relationship between China's financial development and carbon emissions; both the bank loan and money supply are the Granger causes of carbon emissions; specifically, the effect of the bank loan on carbon emissions proves insignificant at $15 \%$ level. Besides, GDP is a Granger cause the change of carbon emissions statistically at $10 \%$ level.

\section{Conclusions}

This article has tested the impact of financial development and economic growth on $\mathrm{CO} 2$ emissions in China. The study has found evidence that carbon emissions are mainly determined by economic growth in the long run. We can see that China's economic growth and carbon emissions increase simultaneously. The rapid economic growth leads to the large demand of energy, then resulted in a significant cause impact of economic growth on environmental pollution. China's successful transition from a centrally planned economy to a market-oriented economy has proved to be phenomenally successful with a tremendous rate of economic growth. In fact, this study has presented evidence of a positive and significant coefficient in the case of economic growth.

However, the results from this paper show a negative sign for the coefficient of financial development, measured using bank loans variable and money supply to GDP, suggesting that financial development in China has not taken place at the expense of environmental pollution. Additionally, it should be noted that the influence magnitude of China's financial intermediation scale expansion on carbon emissions appears to be relative smaller and the effect of financial intermediation efficiency becomes larger and larger, so it will act as a more significant impetus to mitigating carbon emissions although it may cause the change of carbon emissions.
These results are important for several reasons. As an emerging economy, China will continue to develop its financial system and experience an increase in economy. Then, Energy consumption may aggravate environment problems. If energy conservation policies do not include the additional impact of financial development on energy demand, it is not likely to meet greenhouse gas emissions targets. Therefore, the targets must be taken into account the impact of financial development on environment.

\section{ACKNOWLEDGMENT}

I gratefully acknowledge the financial supported by the National Natural Science Foundation of China(approve number:71373076).

\section{REFERENCES}

[1] Perry Sadorsky, The impact of financial development on energy consumption in emerging economies,Energy Policy, vol. 38, 2010,pp. 2528-2535.

[2] Abdul Jalil,Mete Feridun, The impact of growth, energy and financial development on the environment in China: A cointegration analysis , Energy Economics, doi:10.1016/j.eneco.2010.10.003

[3] Yue-Jun Zhang. The impact of financial development on carbon emissions: An empirical analysis in China Energy Policy. Vol.39,2011,pp.2197-2203.

[4] Perry Sadorsky .Financial development and energy consumption in Central and Eastern European frontier economies. Energy Policy,vol.39,2011,pp.999-1006.

[5] Tamazian,A.,BhaskaraRao,B.,2010.Do economic,financial and institutional developments matter for environmental degradation? Evidence from transitional economies. Energy Economics, vol.32,pp.137-145.

[6] Claessens, S., Feijen, E., 2007. Financial sector development and the millennium development goals. World Bank Working Paper No. 89. The World Bank. 